\title{
Trend Analysis of Islamic Financing: A Case of Islamic Banks in Malaysia
}

\author{
Muhammad Hussain Qureshi ${ }^{1 *}$, Talat Hussain ${ }^{2}$ \\ ${ }^{1,2}$ Institute of Islamic Banking (IIB), University of Management and Technology, Lahore, Pakistan \\ ${ }^{1}$ Department of Management Sciences, Virtual University, Lahore, Pakistan
}

\section{Keywords \\ Islamic Banking \\ Financing Modes \\ Financing Portfolio \\ Malaysia}

Received: 11 January 2019

Accepted: 18 May 2020

\begin{abstract}
The objective of this study is to identify and analyze the trend of different modes of financing offered by standalone Islamic banks and Islamic subsidiaries of conventional banks of Malaysia. At present, there are 5 standalone Islamic banks and 11 Islamic subsidiaries of conventional banks operating in Malaysia. All banks are selected for analysis. Annual audited financial statements of standalone Islamic banks and Islamic subsidiaries of conventional banks have been utilized for obtaining data. The study period is from year 2010 to 2016. Vertical and horizontal analysis techniques are applied for analyzing the data. The results indicate that Islamic subsidiaries of conventional banks are more efficient in providing different modes of financing out of 6 popular modes; Islamic subsidiaries of conventional banks are capturing 4 modes which are in double figure as percentage of the total portfolio; while in standalone Islamic banks, 3 modes are in double figure. In sales base products standalone Islamic banks are more efficient, while Islamic subsidiaries of conventional banks are more efficient in providing rental base products. In products like murābaḥah and ijārah, Islamic subsidiaries of conventional banks are more efficient, while standalone Islamic banks are more efficiently managing the controversial products such as Bai Bithaman Ajil and tawarruq. While three products are showing upward trends, the other three are showing downward trend. The study concluded that despite being exalted in Islamic banking and finance, still the Islamic financing base of Malaysian banks comprises the debt creating modes.
\end{abstract}

KAUJIE Classification: K0, K2, K3, K4, K5, K12 JEL Classification: G21, G23, Z12

(C) 2020 JIBM. All rights reserved.

\footnotetext{
${ }^{*}$ Corresponding author: Muhammad Hussain Qureshi is a PhD Scholar at Institute of Islamic Banking (IIB), University of Management and Technology, Lahore, Pakistan

${ }^{\dagger}$ Email: hussain.qureshi@vu.edu.pk
} 


\section{INTRODUCTION}

Islamic financing modes can be divided broadly in different categories, debt-based financing, equity-based financing and hybrid. Debt-based financing includes and its variants, ijārah, salam and istisna etc; Equity-based financings constitute mushārakah and mudārabah, while hybrid financing may include Diminishing mushärakah where the underlying mode is generally . Since the inception of Islamic banking in 1980s, the debate between adoption of debt-based financing or equity-based financing remained a focal point for academicians, practitioners and scholars. Despite the shining fact that equity-based financing is the best choice, Islamic banks are far away from this category of financing (Akin, Iqbal, \& Mirakhor, 2016).

Islamic banking industry in Malaysia can be segregated into two broad categories. Standalone Islamic banks (SAIBs) and Islamic Subsidiaries of conventional banks (ISCBs). According to Bank Nigara Malaysia (n.d) there are 5 standalone and 11 Islamic subsidiaries of conventional banks working in Malaysia. Bank Negara Malaysia (BNM) is the highest regulatory authority for banks in Malaysia (Ibrahim, Mohammad, \& Manjang, 2017). According to a recent report of IFSB (2018), Malaysia is the 4th largest country in term of Islamic banking assets with total of $9.1 \%$ share in global Islamic banking till first half of year 2017 (in first half of Year 2015 \& 2016 it was 9.3\%) share in global Islamic banking assets.

\section{Contribution of the Study}

Present study is motivated by a number of factors. First, it is important to note that since last three years from year 2015 to year 2017 no growth is observed in share of Malaysia in global Islamic banking assets. Secondly, researches that focus on the changes in the modes of financing in relation to their percentage in total financing portfolio and their consequences are less. Third, according to Zaher and Kabir Hassan (2001), activities of Islamic banking are country specific and there are contradictions in theory and practice due to country specific models of Islamic banking. Fourth, previous studies such as Ibrahim and Kamarudin (2014), Ismail, Azmi, and Thurasamy (2014), Shahida and Saharah (2013), and Sulaiman, Majid, and Ariffin (2015), concentrate mainly on issues and challenges related to home financing, corporate governance, preference of $s u k \bar{u} k$ in Malaysia and performance of Islamic banking in Malaysia. To the best of our knowledge, no previous study is done that focuses solely on trends of Islamic financing products in this specific country.

Therefore, this study is aimed to cover this GAP by depicting an insight to the Islamic finance industry of Malaysia, where Islamic and traditional banks are running side by side while no reasonable growth was observed during the three years from year 2015 to 2017 . The main purpose of the study is to perform a detailed analysis of several types of financing modes offered by Islamic banks of Malaysia. Two important analysis tools are horizontal analysis and vertical analysis. Horizontal analysis is used to estimate the differences in the amount of an item in relation to amount of same item in the corresponding financial statements over a period of time (Gibson, 2012). Horizontal analysis, also called as trend analysis, is helpful in estimating the effects of operational results over the sample period (Fridson \& Alvarez, 2011). It is based on two periods where the first period is normally applied as base period and 
all subsequent periods are compared with the base period item (Bernstein, 1993). Another important analysis tool is vertical analysis. It is a relative analysis of financials, in this type of analysis each item of a particular account is presented as a percentage of total of that account (Shaoul, 1998). In general, this study indulges in the following research questions.

\section{Research Questions}

1. What are the different modes of financing offered by SAIBs and ISCBs of Malaysia?

2. What is the worth of each mode of financing offered by SAIBs and ISCBs of Malaysia?

3. What is the trend in each mode of financing offered by SAIBs and ISCBs of Malaysia?

4. Which group of banks is better in providing and managing the Islamic financing modes?

The Objectives of this study is to identify and analyze the share of different modes of financing offered by SAIBs and ISCBs of Malaysia and their trend with the passage of time. This study is also aimed to identify which group of banks is efficient in providing and managing the Islamic financing modes.

\section{LITERATURE REVIEW}

This section reviews the literature related to Islamic financial products. In addition to this, a brief introduction of different financing modes, their importance and definitions as per literature, and as described by Islamic banks, have also been discussed.

The objective of Islamic finance system is to follow the teachings of Qur'ān and Sunnah, which emphasize to avoid contracts containing elements which are against the teachings of Islam (Moin, 1999). The basic difference between the Islamic and conventional systems stems from the prohibitions like that of ribā, gharar and maysir for the former and no such condition observable for the latter (Suzuki \& Uddin, 2016).

There are five basic Islamic financial contracts, these are murābahah, ijārah, ijārah, salam and Istiṣnā'(forward sales), mud̄ärabah and mushärakah (Zaher \& Kabir Hassan, 2001). According to Kahf and Khan (1992), the most influential mode of financing in pre-Islam period was financing based on ribā, while mudārabah was the second most important mode of financing. Supporters of Islamic banking argue that most of the Islamic financial institutions are worked on profit and loss sharing rule and that profit and loss sharing arrangement is preferred over non-profit and loss sharing arrangements for several reasons including risk sharing features (Ebrahim \& Safadi, 1995). On the contrary Aggarwal and Yousef (2000) found that most of the financing provided by Islamic banks are based on debt instruments, these findings are consistent with the findings of Metwally (1992) and Pourian (1995). The financing products offered by Islamic banks can be segregated in to Sharī'ah-based and Sharī'ah-compliant approaches (Cizakca, 2011, p. 3). Mudārabah which is trust based contract and mushärakah which is equity-based contract; both are considered as products which are fully in compliance with the divine rules set by Sharī'ah. Therefore, Islamic banks providing these products are theoretically considered in a better position to defend market risk than traditional banks, because depositor are engaged in loss sharing if occurred (Chong \& Liu, 2009). In contrary, products which are normally utilized for trade financing, and termed as assets-based or debt-based products based on the 'Sharī'ah Compliance' approached. 
From incentive perspective, dominance of murābahah over mushärakah is due to the fact that Islamic bank wants to assure rent (profit) opportunities in investment portfolio (Suzuki \& Uddin, 2016). Hellmann, Murdock, and Stiglitz (1997) argue that banks must maintain a reasonable amount of profit to safeguard its value and reputation as judicious financial institution. Other incentive to earn bank rent is to gain financial expanding especially in developing countries. According to Sairally (2002) banks offered debt based instruments especially murābahah due to its convenience, simplicity and low risk nature as opposed to profit and loss sharing based instruments, these advantages also help banks to gain a competitive advantage over traditional banks.

Yousef (2004) claimed that various systematic forces such as regulatory, institutional and political forces worked opposed to academic assumptions of using profit and loss-based modes of financing in real situation and it ultimately forced Islamic banks to adopt debt-based instruments. Molyneux and Munawar (2005) extended the discussion and added that lack of knowledge of investors and regulators on equity-based modes and unwillingness nature of investors to absorb risk attached with these modes, forced banks to adopt debt-based instruments.

As opposed to above, literature claimed that debt based instruments opened a back door for earning interest, by splitting the transaction in to selling and buying and adding mark up for deferment through credit contract. According to Sairally (2002) in debt based instruments such as muräbahah markup is determined through a bench mark which is normally the traditional interest rate. Thus, it resembles with traditional debt and hence shakens the role of Islamic banking as an alternative to traditional debt financing through equity based financing (Yousef, 2004). Adding criticism to the debate, Zandi, Ariffin, and Shahabi (2012) found that by involving in murābahah mode, banks added trade function to their financial intermediary role. Similarly, absence of true sale, transfer of risk to the purchaser and provocative profits representing the prevailing market interest rates, make this mode artificial.

\section{The Ideal Modes of Financing}

In earlier studies on ideal mode of Islamic financing, Siddiqui (2001) claimed that financing based on profit and loss sharing assures justice between the parties because bank's return depends on the operational results of the businessman. The importance of justice has been emphasized in Al-Qur'ān many times as for example Allah says,

"O you who believe! Stand out firmly for justice, as witnesses to Allah, even if it be against yourselves, your parents, and your relatives, or whether it is against the rich or the poor..." (Qur'ān, 4:135). As per Khaki and Sangmi (2011) profit and loss base financing is a real alternative to interest-based financing because it provides a healthier financing portfolio and ideal allocation of resources not only for the economic growth and welfare of the society at the individual level, but also on the aggregate level. That is the reason that prophet Muhammad (PBUH) was among the poor and later become a popular trader, it is attributed mainly towards the capital provided by Khadija (R.A) on the basis of profit and loss on mudārabah, later become He is(PBUH) wife (Rahman, 2010).

Bilal and Rahim (2014) attributed the perception of people that there was no specific 
difference between Islamic and conventional bank, and that was due to the lack of profit and loss sharing financing instruments because in both systems burden has to be bear by people. That was the reason that renowned scholar Usmani (2004) also termed the profit and loss sharing mode of financing as ideal mode of Islamic finance. Usmani (2004) argued that mudārabah and mushārakah were ideal modes because of their far-reaching impact on production and distribution of wealth.

\section{METHODOLOGY}

\section{Sample and Population}

To achieve the objectives of the study, full-fledge Islamic banks and Islamic subsidiaries of conventional banks operating in Malaysia ${ }^{1}$ have been taken as sample. At present, there are total five full-fledge and eleven Islamic subsidiaries of conventional banks operating in Malaysia , and all banks have been selected for analysis. The study period is from year 2010 to 2016. Post financial crises period is selected for analysis, because after financial crises it was believed that Islamic finance could serve as a vehicle to come out from the global financial crises (Elasrag, 2010). Annual audited financial statements of sample banks were utilized for collecting data. The study is quantitative in nature. Microsoft Excel and EViews 10 have been applied as a trend analysis tools. List of sample banks is as in Table number 1.

TABLE 1

List of Sample Banks

\begin{tabular}{llll}
\hline \hline Sr. & Stand Alone Islamic Banks & Sr. & Islamic Subsidiaries of Conventional Banks \\
\hline 1 & Al Rajhi Bank & 1 & Alliance Islamic Bank \\
2 & Asian Finance Bank & 2 & AmIslamic Bank \\
3 & Bank Muamalat Malaysia Berhad & 3 & Affin Bank \\
4 & Bank Islam & 4 & CIMB Islamic Bank \\
5 & Kuwait Finance House & 5 & HSBC Amanah Malaysia Berhad \\
& 6 & Hong Leong Islamic Bank \\
& 7 & Maybank Islamic Bank \\
& 8 & OCBC \\
& 9 & Public Islamic Bank \\
& 10 & RHB \\
& 11 & Standard Chartered Saadiq Berhad \\
\hline \hline
\end{tabular}

Details regarding the modes of financing and their share in total financing were obtained from notes to the accounts provided in the annual reports of each sample bank. Ratios of each mode of financing were calculated for the period 2010 to 2016. These ratios are then analyzed through trend analysis techniques. Variables and their calculations are provided in Table 2. 
TABLE 2

List of Major Variables and their Calculation

\begin{tabular}{|c|c|c|}
\hline Sr. & Variable & Formula \\
\hline 1 & $B a i^{\triangleleft \wedge}$ Financing & $\begin{array}{l}\text { Total } b a i^{\triangleleft \wedge} \text { financing provided by a sample } \\
\text { bank in a particular year/Total financing pro- } \\
\text { vided by a sample bank in a particular year } \mathrm{x} \\
100\end{array}$ \\
\hline 2 & BBA Financing & $\begin{array}{l}\text { Total BBA financing provided by a sample } \\
\text { bank in a particular year / Total financing pro- } \\
\text { vided by a sample bank in a particular year } x \\
100\end{array}$ \\
\hline 3 & Murābaḥah Financing & $\begin{array}{l}\text { Total murābahah financing provided by a sam- } \\
\text { ple bank in a particular year / Total financing } \\
\text { provided by a sample bank in a particular year } \\
\text { x } 100\end{array}$ \\
\hline 4 & Tawarruq Financing & $\begin{array}{l}\text { Total tawarruq financing provided by a sam- } \\
\text { ple bank in a particular year / Total financing } \\
\text { provided by a sample bank in a particular year } \\
\text { x } 100\end{array}$ \\
\hline 5 & Diminishing mushārakah Financing & $\begin{array}{l}\text { Total DM financing provided by a sample bank } \\
\text { in a particular year / Total financing provided } \\
\text { by a sample bank in a particular year x } 100\end{array}$ \\
\hline 6 & ITAB Financing & $\begin{array}{l}\text { Total ITAB financing provided by a sample } \\
\text { bank in a particular year / Total financing pro- } \\
\text { vided by a sample bank in a particular year } x \\
100\end{array}$ \\
\hline 7 & Average financing & $\begin{array}{l}\text { Total financing provided by all sample banks } \\
\text { for a particular mode from (2010-2016)/ Total } \\
\text { financing provided by all sample banks during } \\
\text { the period (2010-2016) x } 100\end{array}$ \\
\hline
\end{tabular}

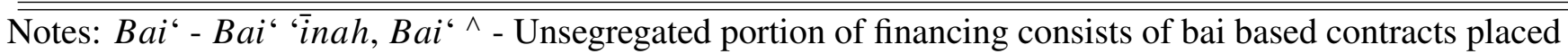
the head $b a i^{\wedge}{ }^{\wedge}$ by some sample banks, BBA-Bai ${ }^{`}$ bithaman ajil, DM-Diminishing mushärakah, IMBTIjārah Muntahiah Bi al-tamlik, ITAB-ijārah, thumma al Bai` 


\section{RESULTS AND ANALYSIS}

TABLE 3

Year Wise Financing Offered by Full-Fledge Islamic Banks 2010-2016

\begin{tabular}{lllllllll}
\hline \hline YEAR & 2010 & 2011 & 2012 & 2013 & 2014 & 2015 & 2016 & All \\
\hline Bai $^{`}$ & 0 & 0 & 0 & 18.89 & 19.22 & 19.89 & 19.91 & 11.13 \\
Bai $^{\wedge}$ & 4.62 & 3.23 & 2.07 & 1.51 & 1.75 & 0.98 & 0.87 & 2.15 \\
BBA & 36.32 & 36.57 & 37.17 & 35.51 & 31.93 & 29.27 & 27.44 & 33.46 \\
Dayn & 2.06 & 2.15 & 1.54 & 1.42 & 1.11 & 1.1 & 0.85 & 1.46 \\
DM & 0.06 & 0.11 & 0.04 & 0.04 & 0 & 0 & 0 & 0.04 \\
Ijārah & 2.12 & 1.95 & 1.09 & 0.59 & 0.44 & 0.19 & 0.16 & 0.94 \\
IMBT & 6.25 & 5.97 & 5.65 & 5.83 & 4.81 & 5.16 & 6.03 & 5.67 \\
Istisnā & 4.87 & 2.74 & 2.13 & 1.46 & 1.22 & 0.33 & 0.29 & 1.86 \\
ITAB & 3.81 & 3.22 & 2.36 & 2.04 & 1.93 & 1.64 & 1.28 & 2.33 \\
Mud̄arabah & 0.37 & 0.28 & 0.33 & 0.25 & 0.22 & 0.21 & 0.21 & 0.27 \\
Murābahah & 19.45 & 17.77 & 15.9 & 15.3 & 17.01 & 15.29 & 14.23 & 16.42 \\
Partnership & 1.37 & 1.23 & 1.29 & 1.08 & 0.88 & 0.66 & 0.69 & 1.03 \\
Qard & 0 & 0 & 0.06 & 0.12 & 0.11 & 0.19 & 0.15 & 0.09 \\
Qard al-Hasan & 0.17 & 0.08 & 0.02 & 0.02 & 0.02 & 0.02 & 0.01 & 0.05 \\
Rahn & 0 & 0 & 0.08 & 0.08 & 0.13 & 0.11 & 0.13 & 0.08 \\
Tawarruq & 18.55 & 24.69 & 30.28 & 15.86 & 19.21 & 24.95 & 27.76 & 23.04 \\
Ujrah & 0 & 0 & 0 & 0 & 0 & 0 & 0 & 0 \\
Wakālah & 0 & 0.02 & 0 & 0 & 0 & 0 & 0 & 0 \\
Others & 0 & 0 & 0 & 0 & 0 & 0 & 0 & 0 \\
Total & 100 & 100 & 100 & 100 & 100 & 100 & 100 & 100 \\
\hline \hline
\end{tabular}

Notes: $B a i^{`}-B a i^{`}{ }^{\circ}$ inah, $B a i^{\wedge} \wedge$-Unsegregated portion of financing consists of bai based contracts placed under the head $b a i^{\wedge} \wedge$ by some sample banks, BBA-Bai ${ }^{`}$ bithaman ajil, DM-Diminishing mushārakah, IMBT-ijārah, Muntahiah Bi al-tamlik, ITAB-Ijārah thumma al bai ${ }^{\star}$

Table 5 provides the rank of each mode of financing in each of the study year (20102016) offered by SAIBs of Malaysia. Top three products of SAIBs of Malaysia are BBA, tawarruq and murābahah. BBA is consistently on 1st position in all 7 years with tawarruq and murābahaha on 2nd and 3rd position. Figures reflecting the position of an early bird capturing the market of popular modes of financing.

Table number 6 provides the rank of each mode of financing in each of the study year (2010-2016) offered by ISCBs of Malaysia. Top three products of ISCBs of Malaysia are BBA, IJAB and murābahah. No specific product is consistently securing 1st, 2nd or 3rd rank in products offered by ISCBs of Malaysia. Results reflecting the efforts of ISCBs in capturing market of different modes of financing. The results also reflecting the late entry of ISCBs in Islamic financial market, due to this late entry products are having fluctuating positions in ranking. 
TABLE 4

Year Wise Financing Offered by Islamic Subsidiaries of Conventional Banks 2010-2016

\begin{tabular}{|c|c|c|c|c|c|c|c|c|}
\hline YEAR & 2010 & 2011 & 2012 & 2013 & 2014 & 2015 & 2016 & All \\
\hline$B a i^{6}$ & 0 & 0 & 0 & 3.99 & 10.38 & 11.3 & 2.88 & 4.19 \\
\hline$B a i^{\triangleleft \wedge}$ & 19.05 & 19.31 & 18.06 & 11.22 & 8.48 & 6.45 & 7.17 & 12.65 \\
\hline BBA & 30.36 & 30.28 & 30.14 & 25.66 & 19.89 & 16.97 & 16.8 & 24.14 \\
\hline Dayn & 0.98 & 0.56 & 0.44 & 0.34 & 0.36 & 0.18 & 0.21 & 0.42 \\
\hline DM & 1.85 & 2.13 & 6.02 & 8.88 & 11.66 & 13.01 & 14.46 & 8.46 \\
\hline Ijārah, & 3.08 & 4.2 & 3.88 & 3.69 & 4.47 & 4.45 & 2.91 & 3.83 \\
\hline IMBT & 5.02 & 3.68 & 4.09 & 4.57 & 3.65 & 4.18 & 4.57 & 4.23 \\
\hline Istișna $\bar{a}^{\prime}$ & 0.65 & 0.24 & 0.07 & 0.02 & 0.01 & 0.72 & 0.53 & 0.31 \\
\hline ITAB & 20.87 & 21.01 & 19.53 & 17.45 & 15.94 & 14.89 & 13.6 & 17.52 \\
\hline Mudāarabah & 0 & 0 & 0 & 0 & 0 & 0 & 0 & 0 \\
\hline Murābaḥah & 10.29 & 10 & 12.33 & 16.61 & 19.36 & 21.6 & 24.09 & 16.49 \\
\hline Partnership & 1.29 & 2.01 & 0 & 0 & 0 & 1.21 & 1.66 & 0.87 \\
\hline Qard & 0 & 0 & 0 & 0 & 0 & 0 & 0 & 0 \\
\hline Qard al-Hasan & 0 & 0 & 0 & 0 & 0 & 0 & 0 & 0 \\
\hline Rahn & 0 & 0 & 0 & 0 & 0 & 0 & 0 & 0 \\
\hline Tawarruq & 0 & 0 & 0 & 0 & 1.88 & 4.04 & 9.93 & 2.32 \\
\hline Ujrah & 0.84 & 0.9 & 0.59 & 0.47 & 0.43 & 0.43 & 0.62 & 0.6 \\
\hline Wakālah & 0 & 0 & 0 & 0 & 0 & 0 & 0 & 0 \\
\hline Others & 5.71 & 5.69 & 4.84 & 7.1 & 3.5 & 0.58 & 0.57 & 3.95 \\
\hline Total & 100 & 100 & 100 & 100 & 100 & 100 & 100 & 100 \\
\hline
\end{tabular}

Notes: $\mathrm{Bai}^{`}$ - Bai` al 'īnah, Bai^ ${ }^{\wedge}$ Unsegregated portion of financing consists of bai based contracts placed under the head $\mathrm{Bai}^{\wedge}$ by some sample banks, BBA-Bai ${ }^{`}$ bithaman ajil, DM-Diminishing mushārakah, IMBT-ijārah, muntahiah Bi al-tamlik, ITAB-ijārah, Thumma al bai

TABLE 5

Rank of each Mode of Financing in SAIBs (2010-2016)

\begin{tabular}{|c|c|c|c|c|c|c|c|c|c|c|c|c|c|c|c|}
\hline YEAR & 2010 & YEAR & 2011 & YEAR & 2012 & YEAR & 2013 & YEAR & 2014 & YEAR & 2015 & YEAR & 2016 & YEAR & All \\
\hline BBA & 36.32 & BBA & 36.57 & BBA & 37.17 & BBA & 35.51 & BBA & 31.93 & BBA & 29.27 & Tawarruq & 27.76 & BBA & 33.46 \\
\hline Murābahah & 19.45 & Tawarruq & 24.69 & Tawarruq & 30.28 & $\mathrm{Bai}^{6}$ & 18.89 & $B a i^{\circ}$ & 19.22 & Tawarruq & 24.95 & BBA & 27.44 & Tawarruq & 23.04 \\
\hline Tawarruq & 18.55 & Murābahah & 17.77 & Murābahah & 15.9 & Tawarruq & 15.86 & Tawarruq & 19.21 & $B a{ }^{*}$ & 19.89 & $B a i^{6}$ & 19.91 & Murābahah & 16.42 \\
\hline IMBT & 6.25 & IMBT & 5.97 & IMBT & 5.65 & Murābahah & 15.3 & Murābahah & 17.01 & Murābahah & 15.29 & Murābahah & 14.23 & $\mathrm{Bai}^{\circ}$ & 11.13 \\
\hline Istișnā & 4.87 & $B a i^{\star \wedge}$ & 3.23 & ITAB & 2.36 & IMBT & 5.83 & IMBT & 4.81 & IMBT & 5.16 & IMBT & 6.03 & IMBT & 5.67 \\
\hline$B a i^{\bullet \wedge}$ & 4.62 & ITAB & 3.22 & Istișnā' & 2.13 & ITAB & 2.04 & ITAB & 1.93 & ITAB & 1.64 & ITAB & 1.28 & ITAB & 2.33 \\
\hline ITAB & 3.81 & Istiṣnā & 2.74 & $\mathrm{Bai}^{\triangleleft \wedge}$ & 2.07 & $B a i^{\star \wedge}$ & 1.51 & $B a i^{\wedge}$ & 1.75 & Dayn & 1.1 & $B a i^{\wedge \wedge}$ & 0.87 & $B a i^{\wedge} \wedge$ & 2.15 \\
\hline Ijärah & 2.12 & Dayn & 2.15 & Dayn & 1.54 & Istișnā' & 1.46 & Istișnā' & 1.22 & $B a i^{\wedge \wedge}$ & 0.98 & Dayn & 0.85 & Istișnā' & 1.86 \\
\hline Dayn & 2.06 & Ijārah & 1.95 & Partnership & 1.29 & Dayn & 1.42 & Dayn & 1.11 & Partnership & 0.66 & Partnership & 0.69 & Dayn & 1.46 \\
\hline Partnership & 1.37 & Partnership & 1.23 & Ijārah & 1.09 & Partnership & 1.08 & Partnership & 0.88 & Istisnnă ${ }^{\prime}$ & 0.33 & Istisnna $\bar{a}^{\star}$ & 0.29 & Partnership & 1.03 \\
\hline Mudārabah & 0.37 & Mudāarabah & 0.28 & Mudārabah & 0.33 & Ijārah & 0.59 & Ijärah & 0.44 & Mudārabah & 0.21 & Mudārabah & 0.21 & Ijārah & 0.94 \\
\hline Qarḍ al-Ḥasan & 0.17 & DM & 0.11 & Rahn & 0.08 & Mudārabah & 0.25 & Mudārabah & 0.22 & Ijārah & 0.19 & Ijārah & 0.16 & Mudạrabah & 0.27 \\
\hline DM & 0.06 & Qard al-Hasan & 0.08 & Qard & 0.06 & Qard & 0.12 & Rahn & 0.13 & Qard & 0.19 & Qard & 0.15 & Qard & 0.09 \\
\hline $\mathrm{Bai}^{6}$ & 0 & Wakālah & 0.02 & DM & 0.04 & Rahn & 0.08 & Qard & 0.11 & Rahn & 0.11 & Rahn & 0.13 & Rahn & 0.08 \\
\hline Qard & 0 & $B a i^{6}$ & 0 & Qard al-Hasan & 0.02 & DM & 0.04 & Qard al-Hasan & 0.02 & Qard al-Hasan & 0.02 & Qard al-Hasan & 0.01 & Qard al-Hasan & 0.05 \\
\hline Rahn & 0 & Qard & 0 & $\mathrm{Bai}^{\circ}$ & 0 & Qarḍ al-Ḥasan & 0.02 & $\mathrm{DM}$ & 0 & DM & 0 & $\mathrm{DM}$ & 0 & $\mathrm{DM}$ & 0.04 \\
\hline Ujrah & 0 & Rahn & 0 & Ujrah & 0 & Ujrah & 0 & Ujrah & 0 & Ujrah & 0 & Ujrah & 0 & Ujrah & 0 \\
\hline Wakālah & 0 & Ujrah & 0 & Wakālah & 0 & Wakālah & 0 & Wakālah & 0 & Wakālah & 0 & Wakālah & 0 & Wakālah & 0 \\
\hline Others & 0 & Others & 0 & Others & 0 & Others & 0 & Others & 0 & Others & 0 & Others & 0 & Others & 0 \\
\hline Others & 0 & Others & 0 & Others & 0 & Others & 0 & Others & 0 & Others & 0 & Others & 0 & Others & 0 \\
\hline Total & 100 & & 100 & & 100 & & 100 & & 100 & & 100 & & 100 & & 100 \\
\hline
\end{tabular}


TABLE 6

Rank of each Mode of Financing in ISCBs (2010-2016)

\begin{tabular}{|c|c|c|c|c|c|c|c|c|c|c|c|c|c|c|c|}
\hline $\begin{array}{l}\text { YEAR } \\
\end{array}$ & 2010 & $\begin{array}{l}\text { YEAR } \\
\end{array}$ & 2011 & $\begin{array}{l}\text { YEAR } \\
\end{array}$ & 2012 & YEAR & 2013 & YEAR & 2014 & $\begin{array}{l}\text { YEAR } \\
\end{array}$ & 2015 & YEAR & 2016 & YEAR & All \\
\hline BBA & 30.36 & BBA & 30.28 & BBA & 30.14 & BBA & 25.66 & BBA & 19.89 & Muräbahah & 21.6 & Muräbahah & 24.09 & BBA & 24.14 \\
\hline ITAB & 20.87 & ITAB & 21.01 & ITAB & 19.53 & ITAB & 17.45 & Murābahah & 19.36 & BBA & 16.97 & $\mathrm{BBA}$ & 16.8 & ITAB & 17.52 \\
\hline$B a i^{\bullet \wedge}$ & 19.05 & $B a i^{\wedge \wedge}$ & 19.31 & $B a i^{\wedge}$ & 18.06 & Murābahah & 16.61 & ITAB & 15.94 & ITAB & 14.89 & DM & 14.46 & Murābahah & 16.49 \\
\hline Murābahah & 10.29 & Murābahạh & 10 & Murābahạh & 12.33 & $B a i^{\iota^{\wedge}}$ & 11.22 & DM & 11.66 & DM & 13.01 & ITAB & 13.6 & $B a i^{\natural \wedge}$ & 12.65 \\
\hline Others & 5.71 & Others & 5.69 & $\mathrm{DM}$ & 6.02 & DM & 8.88 & $B a i^{\circ}$ & 10.38 & $B a i^{\circ}$ & 11.3 & Tawarruq & 9.93 & DM & 8.46 \\
\hline IMBT & 5.02 & Ijārah & 4.2 & Others & 4.84 & Others & 7.1 & $B a i^{\wedge \wedge}$ & 8.48 & $B a i^{i \wedge}$ & 6.45 & $B a i^{\wedge^{\wedge}}$ & 7.17 & IMBT & 4.23 \\
\hline Ijārah & 3.08 & IMBT & 3.68 & IMBT & 4.09 & IMBT & 4.57 & Ijārah & 4.47 & Ijārah & 4.45 & IMBT & 4.57 & $B a i^{6}$ & 4.19 \\
\hline DM & 1.85 & DM & 2.13 & Ijārah & 3.88 & $B a{ }^{6}$ & 3.99 & IMBT & 3.65 & IMBT & 4.18 & Ijārah & 2.91 & Others & 3.95 \\
\hline Partnership & 1.29 & Partnership & 2.01 & Ujrah & 0.59 & Ijārah & 3.69 & Others & 3.5 & Tawarruq & 4.04 & $B a i^{6}$ & 2.88 & Ijārah & 3.83 \\
\hline Dayn & 0.98 & Ujrah & 0.9 & Dayn & 0.44 & Ujrah & 0.47 & Tawarruq & 1.88 & Partnership & 1.21 & Partnership & 1.66 & Tawarruq & 2.32 \\
\hline Ujrah & 0.84 & Dayn & 0.56 & Istiṣnā' & 0.07 & Dayn & 0.34 & Ujrah & 0.43 & Istiṣnā' & 0.72 & Ujrah & 0.62 & Partnership & 0.87 \\
\hline Istișnā' & 0.65 & Istișnā' & 0.24 & Qard al-Ḥasan & 0 & Istișnā' & 0.02 & Dayn & 0.36 & Others & 0.58 & Others & 0.57 & Ujrah & 0.6 \\
\hline Qarḍ al-Hasan & 0 & Qard al-Hasan & 0 & Partnership & 0 & Partnership & 0 & Istiṣnā' & 0.01 & Ujrah & 0.43 & Istișnāa & 0.53 & Dayn & 0.42 \\
\hline$B a i^{6}$ & 0 & $\mathrm{Bai}^{6}$ & 0 & $\mathrm{Bai}^{6}$ & 0 & Qard al-Hasan & 0 & Qard al-Hasan & 0 & Dayn & 0.18 & Dayn & 0.21 & Istișnā' & 0.31 \\
\hline Mudạrabah & 0 & Mudārabah & 0 & Mudạrabah & 0 & Muḍārabah & 0 & Mudārabah & 0 & Qard al-Hasan & 0 & Qard al-Hasan & 0 & Qard al-Ḥasan & 0 \\
\hline Qard & 0 & Qard & 0 & Qard & 0 & Qard & 0 & Partnership & 0 & Muḍārabah & 0 & Mudārabah & 0 & Mudārabah & 0 \\
\hline Rahn & 0 & Rahn & 0 & Rahn & 0 & Rahn & 0 & Qard & 0 & Qard & 0 & Qard & 0 & Qard & 0 \\
\hline Tawarruq & 0 & Tawarruq & 0 & Tawarruq & 0 & Tawarruq & 0 & Rahn & 0 & Rahn & 0 & Rahn & 0 & Rahn & 0 \\
\hline Wakālah & 0 & Wakālah & 0 & Wakālah & 0 & Wakālah & 0 & Wakālah & 0 & Wakālah & 0 & Wakālah & 0 & Wakālah & 0 \\
\hline Total & 100 & & 100 & & 100 & & 100 & & 100 & & 100 & & 100 & & 100 \\
\hline
\end{tabular}

In SAIBs, three products namely BBA, murābahah and tawarruq are providing $27.44 \%$, $14.23 \%, 27.76 \%$ respectively of total financing. Total 69.43\% (in-Year 2010: 74.32\%) financing of SAIBs was based on these three products. On the other hand, in year 2016 the products which were in double figure in ISCBs were BBA, DM, ITAB and murābahah. Total 68.95\% (in-Year 2010: 63.35\%) was based on these four products. However, in year 2010 instead of DM, $b a i^{\star \wedge}$ was is in double figure along with BBA, ITAB and murābahah.

The results indicate that over the past seven years (2010-2016), SAIBs were consistent in the utilization of same modes of financing, but ISCBs changed their business model, dropping the $b a i^{` \wedge}$ and adopting DM. ISCBs were also offering more diversified financing than SAIBs. In case of BBA and muräbahah, there was a tough competition between SAIBs and ISCBs. In 2016, SAIBs were providing $27.44 \%$ and $14.23 \%$ (in-Year 2010: $36.32 \%$ and $19.45 \%$ ) of these two products respectively. While in year 2016, ISCBs captured $16.80 \%$ tawarruq, SAIBs had edge with 27.76\% share in year 2016 (in-Year 2010: 18.55\%). While ISCBs had edge in DM and ITAB with $14.46 \%$ and $13.60 \%$ (in-Year 2010: $1.85 \%$ and 20.87\%) share of financing respectively.

The results tend to build the perception that ISCBs are having expertise in rental based contracts. ISCBs are providing these products with competitive market prices therefore, gaining larger market share of these products. The reason ISCBs are relying on rental base products is that the parent companies are conventional banks, and as per Shiyuti, Khairat, Mourtada, and Ghani (2012) accounting treatment of these products is not different from conventional leasing. This make easy for ISCBs to adopt these products due to their conventional background. For sale-based contract such as tawarruq, SAIBs are gaining larger share due to their better understanding of Sharī'ah rules related to sale-based contracts. Another reason for adopting tawarruq is that in previous years (in 2010 BBA 36\% and in 2016 it was $27 \%$ ) SAIBs were relying on BBA, a controversial product that remained banned in other counties of Middle East. For this reason in year 2008 central bank of Malaysia also issued the ruling against the heavy reliance of Islamic banks on BBA (Abdullah \& Chee, 2010).

Other modes of financing such as, Dayn, ijārah, IMBT, Istiṣna' ', mushārakah, muḍārabah, 
Qard, qard al-hasan, rahn, ujrah and wakälah are just names in the balance sheet of these banks and after over the last seven years these products were not prominent in the financing of these banks. These products are not as useful for Islamic banks as the other, or not providing enough profits, or might be riskier. The results also show that neither SAIBs nor ISCBs are providing salam based contract. This is consistent with the findings of (Muneeza, Yusuf, \& Hassan, 2011) who argue that bankers are more concerned with risk, hesitant to adopt salaam based product in Malaysia due to different risks such as price, delivery, commodity, operational and natural calamity related risks.

\section{Trend Analysis}

Figure 1 represents the trend in total financing offered by SAIBs over the study period 2010-2016. The Y -axis represents the amount of total financing. In SAIBs the total financing is showing an upward trend till 2014, and then in year 2015 and 2016 showing a downward trend.

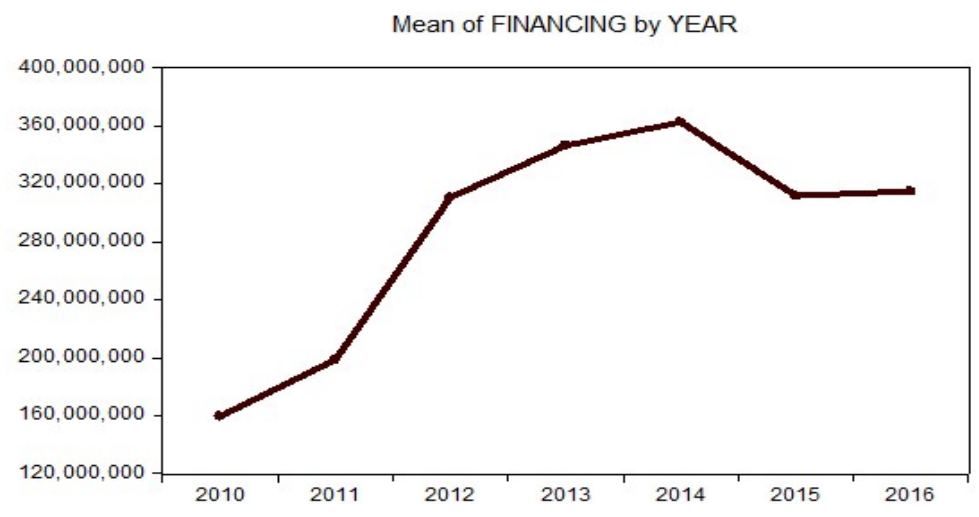

FIGURE 1. Trend in total financing offered by SAIBs

Figure 2 represents the trend in total financing offered by ISCBs over the study period 2010-2016. The Y -axis represents the amount of total financing. In SAIBs the total financing is showing an upward trend throughout the study period.

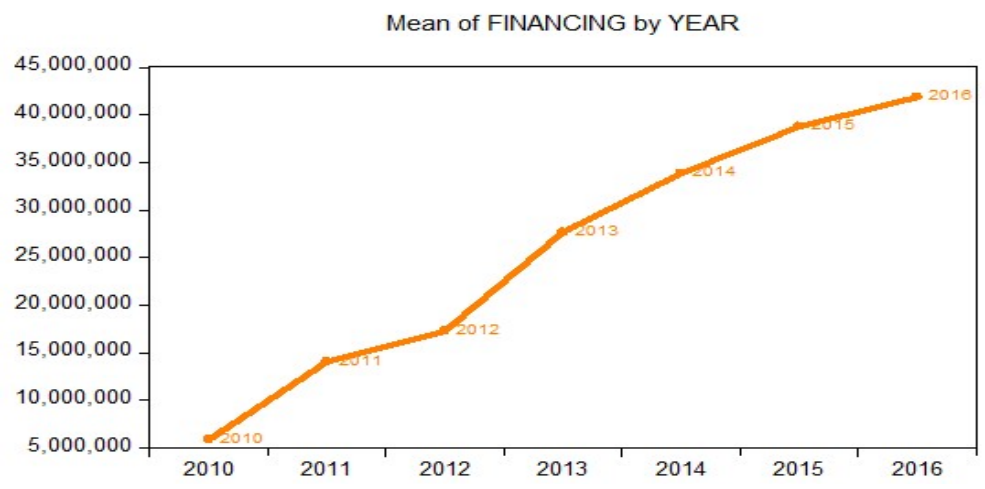

FIGURE 2. Trend in total financing offered by ISCBs 

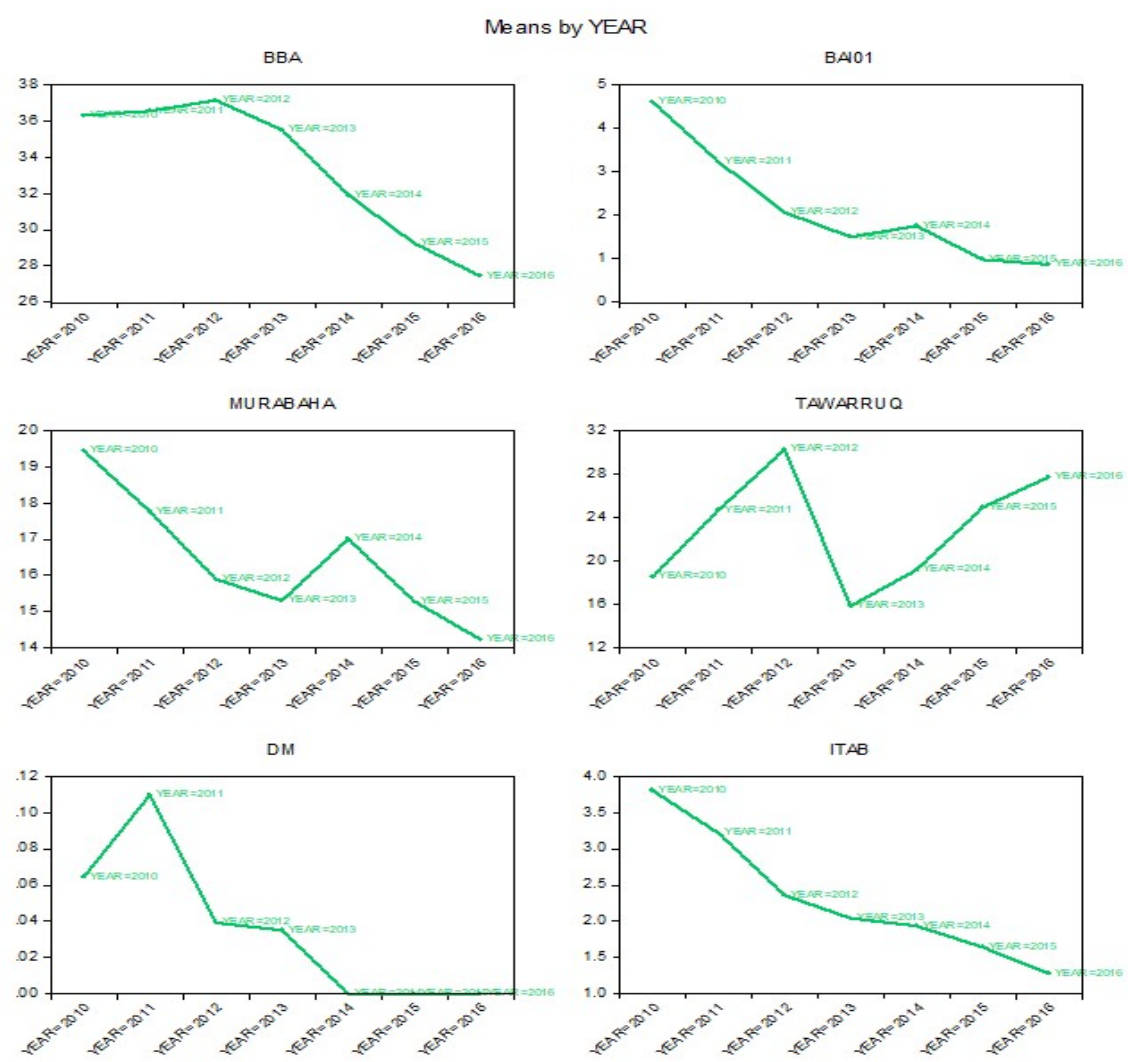

FIGURE 3. Trend in the use of modes in stand alone Islamic banks
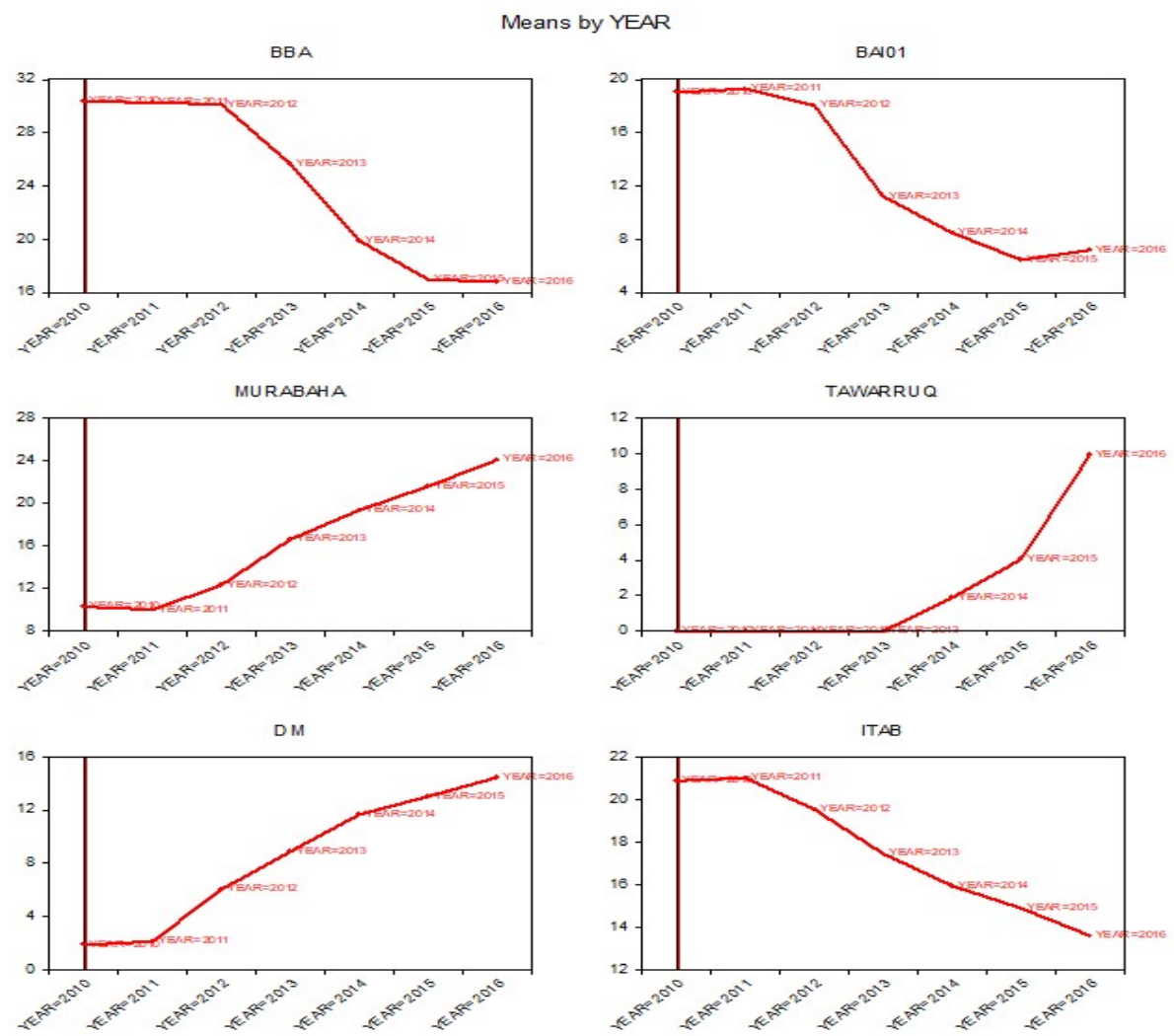

FIGURE 4. Trend in the use of modes in Islamic subsidiaries of conventional banks 
Figure 3 and 4 are showing trend in different financing modes with percentage share in total financing over the year 2010 to 2016 in SAIBs and ISCBs respectively. Y-axis presents the percentage share of financing, and $\mathrm{X}$-axis presents the years in all figures. Both SAIBs and ISCBs are showing a decline in the use of $b a i^{` \wedge}$. The result indicates that $b a i^{\star \wedge}$ which is allowed in Malaysian fiqh but was remained controversial in other counties' fiqh is now losing popularity in Malaysian financial system as well (Abdullah \& Chee, 2010). The results in directly providing the indication towards standardization of Islamic financing modes because similar to Pakistan where $b i^{` \wedge}$ based contracts are not offered Malaysian banks are also moving towards the same. However, in ISCBs despite the downward trend this product still has capturing $7.17 \%$ share in total financing provided in year 2016. All figures in $\%$ are presented in table 3 and 4.

From year 2010 to 2012, the results indicate a tough competition in BBA, with SAIBs showing an upward trend, while ISCBs are showing steady trend. However, after year 2012 both types of banks are showing decline in the use BBA as financing tool. As mentioned above SAIBs are showing more expertise in sale-based contracts (Shiyuti et al., 2012) and this is also reflecting in trend analysis, because despite the declining trend still SAIBs are losing $24.45 \%$ (36.32-27.44/36.32) share, while ISCBs are losing 44.66\% (30.36-16.80/30.36) share. All figures in $\%$ are presented in table 3 and 4.

Murābahah which is also a sale base contract, but in this product, SAIBs are showing downward trend while ISCBs are showing an upward trend. According to (Usmani, 2004) murābahah is only device for protection against interest and is offered for overnight ${ }^{2}$ period only, and this is not the ideal Islamic banking product. It can be inferred from the results that SAIBs are inclining towards ideal modes ${ }^{3}$ of financing and leaving controversial products, this can be also be confirmed from the use of $\mathrm{bai}^{\star \wedge}$, as SAIBs are also utilizing a low portion or even close to zero financing of this mode. However, ISCBs which are inheriting the profit maximization and risk minimization (Cerovic, Suljic Nikolaj, \& Maradin, 2017) motive from the parent companies are inclining towards muräbaḥah financing.

Till year 2012 SAIBs are showing an upward monopolistic trend in the use of tawarruq based contract as financing tool. From year 2012 to 2013 there is a decline and then till year 2016 an upward trending is observing. On the other hand, ISCBs have started offering tawarruq based contract in year 2013 and till year 2016 showing an upward trend and giving tough time to SAIBs, this is also true as per Min, Kim, and Zhan (2017) when new a company enter in a market it reduces the market shares of other competitors, but due to their more expertise in Islamic financing modes SAIBs are still having upper hand in tawarruq financing. All figures in $\%$ are presented in table 3 and 4.

SAIBs are showing a downward trend in the use of DM from year 2011 to 2016. While ISCBs are showing an upward trend in the use of DM throughout the study period. Infect this product is showing a flashing popularity in ISCBs with $1.85 \%$ share in year 2010 to

\footnotetext{
${ }^{2}$ Refers to the starting period when banks are converting their business model from conventional modes to Islamic modes of financing, According to Usmani (2004, p. 165) Sharī'ah scholars have allowed the use of muräbahah and ijärah, only in spares where mushärakah cannot worked and the whole business of banks should not revolve around these two products.
}

${ }^{3}$ According to Usmani (2004, p. 12) mushārakah and mudārabah are the ideal modes of finance. 
$14.46 \%$ share in year 2016. DM as an equity-based financing mode, as per (Chong \& Liu, 2009) Islamic banks providing these products are theoretically considered in a better position to defend market risk than traditional banks, because depositor are engaged in loss sharing if occurred (Chong \& Liu, 2009). However, SAIBs in this product are not very efficient while ISCBs are efficiently capturing the market of DM. In fact ISCBs have monopolistic edge in DM which creates barrier to entry (Starodubrovskaya, 1994) for SAIBs. All figures in \% are presented in table 3 and 4.

Both groups are showing declining trend in the use of ITAB. However, despite the declining trend ISCBs are having upper hand due to two reasons, first despite the declining trend ISCBs have more share $13.60 \%$ (in-Year 2010: $20.87 \%$ ) while SAIBs are having only $1.28 \%$ (in-Year 2010: $3.81 \%$ ) only. Second though it looks that ISCB are losing 7.27\% share (20.87-13.60) of ITAB but in fact it is not losing rather it is shifting from ITAB to DM, because literature claims that debt based instruments are opening a back door for earning interest, by splitting the transaction in to selling and buying and adding mark up for deferment through credit contract. According to Sairally (2002) in debt based instruments such as murābahah markup is determined through a bench mark which is normally the traditional interest rate. Thus, it resembles with traditional debt and hence shaken the role of Islamic banking as an alternate to traditional debt financing through equity based financing (Yousef, 2004). All figures in \% are presented in table 3 and 4.

\section{SUMMARY, CONCLUSION AND RECOMMENDATIONS}

The study was conducted with the objective of identifying and analyzing different modes of financing offered by Standalone Islamic banks (SAIBs) and Islamic Subsidiaries of Conventional banks (ISCBs) of Malaysia. Total of sixteen Islamic banks are operating in Malaysia. Out of these, five are SAIBs and eleven are ISCBs. All sixteen banks are selected for analysis. The data for the period 2010 to 2016 was obtained through annual audited financial statements of sample banks. Vertical and horizontal analysis techniques have been applied for analyzing data. More than 75\% financing of SAIBs and ISCBs consist of BBA, bai ${ }^{` \wedge}$, murābahah, tawarruq, DM and ITAB.

TABLE 7

Summary of Results

\begin{tabular}{lllccccc}
\hline \hline Sr. No. & Product & \multicolumn{2}{l}{ Offering Frequency } & Trend & & \multicolumn{2}{c}{ Average Share in Total Financing \% } \\
\hline & & SAIBs & ISCBs & SAIBs & ISCBs & SAIBs & ISCBs \\
\hline 1 & BBA & 7 & 7 & $\downarrow$ & $\downarrow$ & 33.46 & 24.14 \\
2 & Bai ${ }^{\wedge}$ & 7 & 7 & $\downarrow$ & $\downarrow$ & 2.15 & 12.65 \\
3 & Murābahah & 7 & 7 & $\downarrow$ & $\uparrow$ & 16.42 & 16.49 \\
4 & Tawarruq & 7 & 3 & $\uparrow$ & $\uparrow$ & 23.04 & 2.32 \\
5 & DM & 4 & 7 & $\downarrow$ & $\uparrow$ & 0.04 & 8.46 \\
6 & ITAB & 7 & 7 & $\downarrow$ & $\downarrow$ & 2.33 & 17.52 \\
Total & & & & & & 77.44 & 81.58 \\
\hline \hline
\end{tabular}


$B a i^{` \wedge}$, DM and ITAB are prime products of ISCBs, while BBA and tawarruq are prime products of SAIBs. In muräbahah both groups are having around equal share. In muräbahah, tawarruq and DM, ISCBs are showing upward trend, while SAIBs are showing upward trend in only one product that is tawarruq. ISCBs are focusing the divarication theory of minimizing risk and offering diversified and less risky product, while SAIBs are focusing on only three contracts, which, of course are also less risky.

ISCBs are more efficient in providing different modes of financing-out of 6 popular modes they are capturing 4 modes which are in double figure namely BBA, bai ${ }^{` \wedge}$, murābahah and ITAB, while in case of SAIBs, 3 modes which are in double figure are BBA, murābahah and tawarruq. In sales base product, SAIBs are more efficient, while ISCBs are more efficient in providing rental base product. In case of modes like bai ${ }^{` \wedge}$, murābahah and ijärah, ISCBs are more efficient, while SAIBs are more efficiently managing the products like BBA and tawarruq. Three products namely murābahah, tawarruqand DM are showing upward trends, while other three products including BBA, bai ${ }^{\triangleleft \wedge}$ and ITAB are showing downward trend.

Malaysia that is considered by some as the role model ${ }^{4}$ in Islamic financial industry, yet its Islamic finance industry is lacking in ideal modes of financing such as mushärakah and mudārabah. The Islamic banking sector of Malaysia preferred the sale base modes of financing. Other modes of financing consist of only a nominal portion of total financing. Salam-based products are also not in the list of financing modes offered by these banks. The result is consistent with the economic condition of the country, where the agriculture sector is contributing only a minor portion of total GDP ${ }^{5}$. Islamic financing products fulfill all types of financing needs in each reign according to their economic conditions. Malaysia is a trade base country; therefore, sales-based products are strengthening roots in the economy. Although the competition is high between SAIBs and ISCBs, still ISCBs are performing well in terms of providing and managing Islamic financing modes. The result reflects the expertise of conventional banks due to their experience in the field of banking and can become a threat to SAIBs.

\section{REFERENCES}

Abdullah, D. V., \& Chee, K. (2010). Islamic finance: Understanding its principles and practices. Singapore: Marshall Cavendish International Asia Pte Ltd.

Aggarwal, R. K., \& Yousef, T. (2000). Islamic banks and investment financing. Journal of Money, Credit and Banking, 32(1), 93-120. doi: https://doi.org/10.2307/2601094

Akin, T., Iqbal, Z., \& Mirakhor, A. (2016). The composite risk-sharing finance index: Implications for Islamic finance. Review of Financial Economics, 31, 18-25. doi: https://doi.org/10.2307/2601094

Bank Nigara Malaysia. (n.d). List of licensed financial institutions. Retrieved from https://rb.gy/k2x86i

\footnotetext{
${ }^{4}$ According to Jamaldeen (2010) Islamic and non-Islamic counties are referring Malaysia as role model in the governance of Islamic finance

${ }^{5}$ https://www.statista.com/statistics/318732/share-of-economic-sectors-in-the-gdp-in-malaysia/
} 
Bernstein, L. A. (1993). Analysis of financial statements. New York, NY: Irwin Professional Publishing.

Bilal, Q., \& Rahim, M. (2014). Diminishing mushārakah: A mode of financing in interest free banks. Abasyn University Journal of Social Sciences, 7(1), 150-157.

Cerovic, L., Suljic Nikolaj, S., \& Maradin, D. (2017). Comparative analysis of conventional and Islamic banking: Importance of market regulation. Ekon. Misao I Praksa 26(1), 241-263.

Chong, B. S., \& Liu, M. H. (2009). Islamic banking: Interest-free or interest-based? PacificBasin Finance Journal, 17(1), 125-144. doi: https://doi.org/10.1016/j.pacfin.2007.12.003

Cizakca M. (2011). Islamic capitalism and finance: Origins, evolution and the future. Cheltenham, UK: Edward Elgar Publishing. doi: https://doi.org/10.4337/9780857931481

Ebrahim, M. S., \& Safadi, A. (1995). Behavioral norms in the Islamic doctrine of economics: A comment. Journal of Economic Behavior E Organization, 27(1), 151-157. doi: https://doi.org/10.1016/0167-2681(94)00029-E

Elasrag, H. (2010). Global financial crisis and Islamic finance. Munich Personal RePEc Archive (MPRA), Munich University Library, Munich, Germany. doi: https://doi.org/10.2139/ssrn.1591563

Fridson, M. S., \& Alvarez, F. (2011). Financial statement analysis: A practitioner's guide (Vol. 597). New Jersey, NJ: John Wiley \& Sons. doi: https://doi.org/10.2307/2601094

Gibson, C. (2012). Financial reporting and analysis. Toronto, Canada: Nelson Education.

Hellmann, T., Murdock, K., \& Stiglitz, J. (1997). Financial restraint: Towards a new paradigm. In M. Aoki, H. K. Kim., \& Okuno-Fujiwara, M. (Eds.), The role of government in East Asian economic development comparative institutional analysis. Oxford, UK: Clarendon Press.

doi: https://doi.org/10.1093/acprof:oso/9780198294917.003.0006

Ibrahim, M. F., Mohammad, N. M. F. N., \& Manjang, M. (2017). Comparative analysis of regulation and supervision of Islamic banking between Malaysia and Gambia. Labuan e-Journal of Muamalat and Society (LJMS), 11, 51-58.

Ibrahim, M. F., \& Kamarudin, R. (2014). The Islamic home financing in Malaysia Istisnna base on debt: Qualitative approach. Labuan e-Journal of Muamalat and Society, 8, 27-38.

Ismail, S., Azmi, F., \& Thurasamy, R. (2014). selection criteria for Islamic home financing in Malaysia. International Journal of Business $\mathcal{E}$ Society, 15(1), 97-110.

Jamaldeen, F. (2010). Staying ahead of the competition in Islamic financing. Retrieved from: URL: shorturl.at/nxCFS

Kahf, M., \& Khan, T. (1992). Principles of Islamic financing (Working Research Paper No. 16). Islamic Research and Training Institute, Islamic Development Bank, Jeddah, KSA. Khaki, A., \& Sangmi, M. U. D. (2011). Islamic banking: Concept and methodology. SSRN Electronic Journal, 1-19. doi: https://doi.org/10.2139/ssrn.2184856 
Metwally, S. (1992). The aggregate balance sheet and the results of transactions and financial indicators for Islamic banks and financial institutions. Journal of Islamic Banking and Finance, 1(1), 7-61.

Min, S., Kim, N., \& Zhan, G. (2017). The impact of market size on new market entry: A contingency approach. European Journal of Marketing, 51(1), 177-199. doi: https://doi.org/10.1108/EJM-12-2013-0696

Moin, S. A. (1999). The growing popularity of Islamic banking. Middle East, 291, 33-35.

Molyneux, P., \& Munawar, I. (2005). Banking and financial systems in the Arab world. London, UK: Palgrave Macmillan. doi: https://doi.org/10.1057/9780230512122

Muneeza, A., Yusuf, N. N. A. N., \& Hassan, R. (2011). The possibility of application of salam in Malaysian Islamic banking system. Humanomics, 27(2), 138-147. doi: https://doi.org/10.1108/08288661111135135

Pourian, H. (1995). The experience of Iran's Islamic financial system and its prospect for de velopment. In Development of financial markets in the Arab countries, Iran and Turkey. Economic Research Forum for the Arab Countries, Iran, and Turkey, Cairo, Egypt.

Rahman, A. R. A. (2010). Islamic microfinance: An ethical alternative to poverty alleviation. Humanomics, 26(4), 284-295. doi: https://doi.org/10.1108/08288661011090884

Sairally, B. S. (2002). Murābahah financing: Some controversial issues. Review of Islamic Economics, 12, 73-86.

Shaoul, J. (1998). Critical financial analysis and accounting for stakeholders. Critical Perspectives on Accounting, 9(2), 235-249. doi: https://doi.org/10.1006/cpac.1997.0172 Shahida, S., \& Saharah, S. (2013). Why do firms issue șukük over bonds? Malaysian evidence. Paper presented at the 15th Malaysian Finance Association Conference, 2, 551-573.

Shiyuti, H. A., Khairat, D., Mourtada, M., \& Ghani, M. (2012). Critical evaluation on AlIjārah, Ijārah Thummalbai'. Paper presented at the Asian Finance Association (AsFA) 2013 Conference, Seoul, Korea. doi: https://doi.org/10.2139/ssrn.2184296

Siddiqui, S. H. (2001). Islamic banking: True modes of financing. New Horizon, 109(2), $15-20$.

Starodubrovskaya, I. (1994). The nature of monopoly and barriers to entry in Russia. Communist Economies and Economic Transformation, 6(1), 3-18. doi: https://doi.org/10.1080/14631379408427776

Sulaiman, M., Abd Majid, N., \& Ariffin, N. M. (2015). Corporate governance of Islamic financial institutions in Malaysia. Asian Journal of Business and Accounting, 8(1), 65-94.

Suzuki, Y., \& Uddin, S. S. (2016). Recent trends in Islamic banks' lending modes in Bangladesh: An evaluation. Journal of Islamic Accounting and Business Research, 7(1), 28-41. doi: https://doi.org/10.1108/JIABR-07-2013-0026

Usmani, T. (2004). An introduction to Islamic finance. Karachi, Pakistan: Arham Shamsi. Yousef, T. M. (2004). The murābahah syndrome in Islamic finance: Laws, institutions and politics. In C. M. Henry, \& R. Wilson (Eds.), The politics of Islamic finance. Edinburgh University Press, Edinburgh, UK. doi: https://doi.org/10.3366/edinburgh/9780748618361.003.0003 
Zaher, T. S., \& Kabir Hassan, M. (2001). A comparative literature survey of Islamic finance and banking. Financial Markets, Institutions $\mathcal{E}$ Instruments, 10(4), 155-199. doi: https://doi.org/10.1111/1468-0416.00044

Zandi, G., Ariffin, N. M., \& Shahabi, A. (2012). Some issues on murābaḥah practices in Iran and Malaysian Islamic banks. African Journal of Business Management, 6(24), 7066-7073. doi: https://doi.org/10.5897/AJBM11.2859

$* * * * * * * * * * * * * * * *$ 